\title{
Citizenship Education for Child Citizens
}

\author{
Brian Howe (University College of Cape Breton)
}

\begin{abstract}
One important reason for the inadequacy of current citizenship education is that children - defined here as all young persons under age 18 - are rarely seen and treated as citizens in their own right. To the extent that children are educated about citizenship, they typically learn about their rights and responsibilities as future adult citizens. They rarely learn that they are citizens of the present and they are rarely treated as such. This article reviews the modern meaning of citizenship and shows, in reference to the UN Convention on the Rights of the Child, that children indeed are citizens of the present. It shows that when the ingredients of the modern understanding of citizenship are applied to children - rights, responsibilities, participation, and differentiated citizenship children need to be recognized as citizens. Such an understanding, it is contended, is a necessary foundation for successful citizenship education.
\end{abstract}

Résumé : Une cause importante du caractère inadéquat de l'éducation à la citoyenneté actuelle est que les enfants - définis ici comme toutes les personnes de moins de 18 ans sont rarement vus et traités comme des citoyens à part entière. Dans la mesure où les enfants sont éduqués à propos de la citoyenneté, ils apprennent habituellement des notions sur leurs droits et responsabilités qu'ils auront une fois adultes. Ils apprennent rarement qu'ils sont déjà eux-mêmes des citoyens et qu'ils devraient être traités comme tels. Cet article analyse la signification moderne de la citoyenneté et montre, en se basant sur la Convention des Droits de l'enfant des Nations-Unies, que les enfants sont effectivement des citoyens dans le présent. Ainsi, lorsque les ingrédients de la compréhension moderne de la citoyenneté sont appliqués aux enfants - droits, responsabilités, participation et citoyenneté différenciée -, les enfants doivent être reconnus comme citoyens. L'auteur soutient qu'une telle compréhension est un fondement nécessaire pour la réussite de l'éducation à la citoyenneté.

\section{Failure of Citizenship Education and Conception of Child as Citizen}

Recent studies of citizenship education conducted by Judith Torney-Purta and her colleagues (2001) across 28 countries consistently demonstrate that current approaches are failing to meet the goals of providing students with the knowledge, skills and motivations that promote democratic citizenship. Wondering about possible reasons for this failure, this article suggests that the lack of recognition and treatment of the child as citizen is significant to the inadequacy of current approaches to education for citizenship. 


\section{The Modern Meaning of Citizenship}

The modern conception of democratic citizenship has evolved to include at least four basic ingredients or qualities, beyond the narrow legal definition of citizenship as simply legal membership in a political community. A first ingredient is the enjoyment of basic rights. Writing after the Second World War, British sociologist T.H. Marshall (1950) made the case that what was central to citizenship was not simply legal membership in a political community but also the sense of membership or belonging. For Marshall, what was necessary to giving people a sense of belonging was their possession and enjoyment of basic rights. If people in a political community have basic political, civil, and social rights, and know that they have these rights, they will have the sense that they have value and thus that they belong. Having these rights, they will be sent the message by society that they are true members of their political community.

A second ingredient is the exercise of responsibilities. As pointed out by Will Kymlicka and Wayne Norman (1995) among others, possessing rights is an inadequate component of citizenship. Too much focus on individual rights allows for, or even promotes, passivity among citizens and inordinate attention on private life. It encourages a self-regarding or entitlement culture where citizens are centered on their own rights and interests without sufficient attention to their broader social responsibilities as citizens. If all that citizens did was to focus on their own rights and private interests, the long-term health and viability of a liberal democratic society, supportive of rights, would be put into jeopardy. Who would be there to support it? Thus the concept of citizenship has to make room for responsibilities as well as rights. Exercising social responsibility is important because it gives support to the political community. Laws have to be obeyed and the rights of others have to be respected. It also is important because it contributes to promoting the sense of belonging so desired by Marshall. One is more likely to feel connected to community if one is exercising social responsibility.

A third quality is active participation, as given emphasis by Carole Pateman (1970) and in studies of participatory democracy in the tradition of Pateman (Berman, 1997). From this perspective, participation is connected to having rights and responsibilities but it is more than this. That citizens have the right to input into decision-making provides them with an opportunity for participation. But in a liberal democratic society, citizens also have the right not to participate (or be apathetic). Thus having a sense of social responsibility is also a component of participation. However, opportunities have to be in place for the exercise of responsibility. The main point about participation is that although it is connected to both rights and responsibilities, it is also important to citizenship in its own right. It is a practice that is learned through experience in society - in families, schools, voluntary associations, workplaces - that promotes a sense of efficacy and, in turn, the actual exercising of the rights and responsibilities of citizenship. According to Pateman (1970, p. 105), "we learn to participate by 
participating." From democratic participation come feelings of political efficacy, which in turn lead to a sense of social responsibility and to further participation. Participation is important because it gives life to democratic citizenship and because it contributes to a key purpose of citizenship - promoting a sense of belonging.

Finally, a fourth ingredient is differentiated citizenship or pluralistic citizenship as given attention by Iris Young (1989). Marshall had made the case for uniform or common citizenship: that all citizens would have a sense of belonging through having and enjoying the same rights of citizenship. For Young, this is problematic in that it raises difficulties for promoting a sense of belonging and inclusion. If uniform or common citizenship is pursued completely, and if group differences within a political community are ignored or downgraded, members of many groups may feel excluded or slighted, the effect contrary to the sense of belonging held to be so important by Marshall. For example, special treaty rights or traditional hunting rights are important for many aboriginal communities. Rights associated with multiculturalism are important for many ethnic and cultural minorities. An emphasis on common citizenship rights without regard to group differences would be detrimental to promoting a sense of belonging among these groups. Thus for Young and others, in order to cultivate the sense of belonging, it is better to recognize group differences in citizenship and the different configuration of rights and responsibilities for different groups in society. Although some rights of citizenship may be shared, other rights are unique and differentiated.

\section{The Exclusion of Children as Citizens}

Understanding citizenship to include rights, responsibilities, participation, and group differentiation is a welcome development. But what is not welcome is the exclusion of children as citizens. As a matter of legality, children are legal citizens in virtually all states of the world by virtue of birth or naturalization. But as a matter of adult consciousness and practice, they are not recognized and treated as citizens. They tend to be either ignored as citizens or regarded in an adult-centric fashion as citizens of the future rather than of the present. They typically are seen not as citizens but as "not-yets" or "pre-citizens" (Stasiulis, 2002. p. 509).

In the literature on citizenship, for example, there has been a major focus on the need for social inclusion and to incorporate women, minorities, and marginalized groups into citizenship (Hébert, 2002). Important though this is, very little attention has been given to children as citizens. In the literature on citizenship education in schools, major attention has been given to ways to prepare and train children for future adult citizenship. Books have been written on the subject of educating "tomorrow's citizens" (Pearce \& Hallgarten, 2000). The function of schools has been described as preparing "each new generation 
for their responsibilities as citizens" (Kymlicka, 2001, p. 293). But the concept of children as citizens in the here and now has been noticeably absent. Reviews of curricula materials and of citizenship education programs show that attention continues to be given to children as tomorrow's citizens, not as today's citizens with today's rights of citizenship (Howe \& Covell, 2005).

When the possibility of child citizenship is raised, the principle is rejected on the basis that children do not have the means or capacity to meet the standards of adult citizenship. One argument against children as citizens is their economic dependency (Coles, 1995). Dependent on their parents or guardians, they are not in a position to form autonomous views and to make the independent judgments necessary for the practice of citizenship. They are likely to be unduly swayed by their parents or other adult authorities. But the problem with this argument is that could be used against many groups who make claims for inclusion in citizenship: stay-at-home mothers or fathers or many university students, seniors, and adults with disabilities who are in a financially dependent situation. It is dangerous to make financial independence a strict requirement for citizenship. While dependence may influence the way some people form opinions or make decisions in relation to citizenship, this does not justify the blanket denial of citizenship and the rights and responsibilities that go with it. Citizenship is about inclusion, not economic independence.

Another and more serious argument against child citizenship is that children, unlike adults, do not have the rational capacity for citizenship as they do not have the necessary cognitive development, level of maturity, and self-control (Purdy, 1992; Roche, 1999). It is in the best interests of children not to be burdened with the rights and responsibilities of citizenship. Childhood is a period in which children need to have their actions controlled and their freedoms curtailed such that they are able to acquire the self-control and maturity necessary for responsible adulthood and citizenship. However, a problem with this argument is that it draws too sharp of a distinction between childhood and adulthood (Flekkoy \& Kaufman, 1997). There is no magic moment when a child suddenly becomes an adult. Development occurs across the lifespan and much of it is incremental. Moreover, there is much evidence that the cognitive ability of children increases when they are treated with respect and assumed to be capable (Alderson, 1992). Another problem with the argument is that it assumes some threshold level of rationality as a requirement for citizenship. Even if one could identify with precision what this threshold level is, the assumption of rationality as a requirement runs contrary to the essential meaning of citizenship derived from Marshall. Citizenship is about inclusion and belonging, not cognitive ability. Although we may agree that some forms of participation require a certain general level of maturity (e.g., voting in national elections), this does not mean that children have nothing to offer as citizens through age-appropriate forms of participation. Citizenship is not reducible to voting. 


\section{Understanding Children as Citizens}

If it is agreed that the major ingredients of citizenship include rights, responsibilities, participation, and differentiated citizenship, and that a key purpose is to cultivate a sense of belonging, the question is whether or not children qualify as citizens. If we apply each of these ingredients to children, we see that they do qualify.

First, children qualify as citizens in light of the concept of differentiated citizenship. On the one hand, they have certain rights and responsibilities similar to those of adults under the domestic law of many states and under international law and conventions. For example, it is widely accepted that children have a basic right to life and security of person. They also have the same general responsibility to obey the law and respect the rights of others. But on the other hand, they have rights and responsibilities particular to children as a class of persons. For example, they have the right to protection from abuse and neglect in the home. They also have responsibility to obey the law (assuming the law to be a just law) but in accordance with their age and maturity. As young offenders, their level of responsibility and accountability is not the same as for adults. In short, like other groups of citizens, child citizens have a somewhat different configuration of the rights and responsibilities of citizenship. They cannot be ruled out as citizens simply because they do not have the same rights and responsibilities as others.

Second, children qualify as citizens on the basis of having certain basic rights. The most comprehensive statement on the rights of the child is found in the UN Convention on the Rights of the Child, a legally binding international treaty ratified by almost all countries of the world (Verhellen, 1997). By ratifying the Convention, states have agreed to recognize and provide for children's rights to protection (e.g., from abuse, neglect, economic exploitation, sexual exploitation), to provision (e.g., of basic needs such as health care and economic welfare), and to participation in decisions affecting the child. What is unique about these rights, in line with the concept of differentiated citizenship, is that they are to be exercised in accord with the "evolving capacities" of the child, with the guidance of parents or guardians, and with the assistance of the state. State authorities have the important obligation to ensure the implementation of the rights of the child.

Third, children are citizens by virtue of having responsibilities of citizenship. As with their rights, the exercise and level of their responsibilities is recognized to be in accord with their evolving capacities. Child citizens have the same general responsibility as adults to obey the law and respect the rights of others. But the level of responsibility expected from a child citizen is age-differentiated. Very young children, for example, have a moral responsibility to obey the law but not legal accountability. Older children have a legal as well as a moral responsibility to do so, but not full legal responsibility and accountability. Most countries have 
juvenile justice systems in which young offenders are held accountable for breaking the law but not to the same degree as adults. Older children also have age-appropriate political responsibility such as voting in student elections or doing community service in schools. In short, in line with their evolving capacities, child citizens do have the responsibilities of citizenship.

Fourth, children qualify as citizens on the basis of their participation in the political community. It is important, however, that the meaning of child participation be clear. According to article 12 of the Convention, children have the right to participate in decisions affecting them, their views to be given weight in accord with their age and maturity. What this means is that although the views of children need not be decisive, children do have the right to input into decisions that affect them, whether in families, schools, local communities, or wider decision-making bodies (Hodgkin \& Newell, 1998). This does not imply that they have the right to participate in the same form and at the same level as adult citizens (e.g., in voting or running for office in national elections). But it does mean that child citizens have the right to be heard in an ageappropriate fashion and that decision-making authorities have the obligation to listen and give weight to the voices of children in relation to their age and maturity.

\section{From Principle to Practice}

As a matter of principle, the right of the child citizen to participate in decisionmaking is recognized globally by virtue of the fact that almost all the countries of the world have ratified the Convention. In agreeing to article 12, states have agreed not only to the right but also to their obligation to assist in providing for this right by putting into place structures, mechanisms, and processes to facilitate child participation. However, as a matter of practice, the extent of child participation is limited, haphazard, and very incomplete, reflecting a lack of adult and state commitment to the principle of child citizenship. Although child participation does takes place in democratic families, democratic classrooms, and processes that allow for child and youth input in community decisionmaking, the practice is sporadic rather than comprehensive. If commitment actually existed, child citizen participation would be practiced on a much wider scale.

The practice of child participation is desirable not only because it is a right but also because it is beneficial to democracy. If we think of democracy as participatory democracy, rather than simply electoral and representative democracy, child participation is a force for healthier democracy. A participatory democracy requires a participatory society where democratic participation takes place in families, schools, and daily life. Through early participation, child citizens develop a sense of efficacy, empowering them to become more active participants in a later practice of citizenship (Pateman, 
1970; Berman, 1997). And if we also think of democracy as deliberative democracy, where decision-making is based on a deliberative process of discussion, debate, and learning the perspectives of all parties affected by a decision, child participation is a force for healthier democracy (Kulynych, 2001; Young, 1997). Through inviting and gaining the perspectives of all parties including children, and through taking into account the interests of all parties including children, decision-makers will be in a position to make better decisions and more legitimate decisions.

\section{Conclusion: Child as Citizen Basic for Robust Citizenship Education}

Thus the basic ingredients of citizenship apply to children as well as to adults. Like adults, children have a need for a sense of belonging to their community. If a key purpose of citizenship is to promote a sense of belonging and a sense of value, then it is important that children and youth be recognized for who they are - citizens. It is important that they not be devalued and belittled as immature not-yets and pre-citizens who are in need of training. The problem is that they are seldom recognized as the citizens that they are. Treated as mere not-yets, many children and youth feel a deep sense of exclusion and alienation from society (Berman, 1997; Scales et al, 2001). This reflects a failure in the practice of inclusive citizenship and in programs of citizenship education in schools.

What is necessary is a robust program of citizenship education in schools that is consistent with the status of children as citizens. As detailed elsewhere (Howe \& Covell, 2005), children's rights education (contextualized in and informed by the UN Convention on the Rights of the Child) is effective in providing citizenship education that is engaging and participatory and that teaches children about their rights and responsibilities as citizens of today as well as of tomorrow. The main point here is that an important step in the direction of developing effective citizenship education is to begin by recognizing and respecting children as citizens. If the key purpose of citizenship is to cultivate a sense of belonging and a sense of value, the recognition of children as citizens is essential to this enterprise.

\section{References}

Alderson, P. (1992). The rights of children and young people. In A. Coote (Ed.), The welfare of citizens developing new social rights (pp. 153-180). London: Institute for Public Policy Research.

Berman, S. (1997). Children's social consciousness and the development of social responsibility. Albany: State University of New York Press.

Coles, B. (1995). Youth and social policy: Youth citizenship and young careers. London: ULC Press.

Flekkoy, M. \& Kaufman, N. (1997). The participation rights of the child. London: Jessica Kingsley.

48 Canadian and International Education Vol. 34 no. 1 - June 2005 
Hébert, Y. (2002). Citizenship in transformation in Canada. Toronto: University of Toronto Press.

Hodgkin, R., \& Newell, P. (1998). Implementation handbook for the convention on the rights of the child. New York: United Nations Children's Fund.

Howe, R. B., \& Covell, K. (2005). Empowering children: Children's rights education as a pathway to citizenship. Toronto: University of Toronto Press.

Kulynych, J. (2001). No playing in the public sphere: Democratic theory and the exclusion of children. Social Theory and Practice 27, 231-264.

Kymlicka, W. (2001). Politics in the vernacular: Nationalism, multiculturalism, and citizenship. Oxford: Oxford University Press.

Kymlicka, W., \& Wayne, N. (1995). Return of the citizen: A survey of recent work on citizenship theory. In R. Beiner (Ed.), Theorizing citizenship (pp. 283-322). Albany: State University of New York Press.

Marshall, T. H. (1950). Citizenship and social class. Cambridge: Cambridge University Press.

Pateman, C. (1970). Participation and Democratic Theory. Cambridge: Cambridge University Press.

Pearce, N., \& Hallgarten, J. (2000). Tomorrow's citizens: Critical Debates in citizenship and education. London: Institute for Public Policy Research.

Purdy, L. (1992). In their best interest. Ithaca: Cornell University Press.

Roche, J. (1999). Children: Rights, participation and citizenship. Childhood 6, 475-493.

Scales, P., Benson, P., Roehlkepartain, E., Hintz, N., Sullivan, T., \& Mannes, M. (2001). The role of neigborhood and community in building developmental assets for children and youth. Journal of Community Psychology 29,703-727.

Stasiulis, D. (2002). The active child citizen: Lessons from Canadian policy and the children's movement. Citizenship Studies 6, 507-538.

Torney-Purta, J., Lehmann, R., Oswald, H., \& Schultz, W. (2001). Citizenship and education in twenty eight countries. Amsterdam: The International Association for the Evaluation of Educational Achievement.

Verhellen, E. (1997). Convention on the rights of the child: Background, motivation, strategies, main themes. Leuven Apeldoorn: Garant.

Young, I. (1989). Polity and group difference: A critique of the ideal of universal citizenship. Ethics 99, 250-274.

Young, I. (1997). Difference as a resource for democratic communication. In J. Bohman \& W. Rehg (Eds.), Deliberative democracy (pp. 383-406). Cambridge, MA: MIT Press. 